\title{
PENINGKATAN HASIL BELAJAR PAI MATERI BERWUDHU MELALUI METODE DEMONSTRASI PADA PESERTA DIDIK KELAS II DI SDN HARGOWILIS
}

\author{
I'ing Hildah \\ SD Negeri Sanggrahan, Kulon Progo, Indonesia \\ iinghilda.uad@gmail.com \\ DOI: 10.20885/tarbawi.vol14.iss1.art2
}

\begin{abstract}
This study aims to determine the increase in learning outcomes of ablution material after using the demonstration method. This research is a classroom action research conducted on second grade students at SD Negeri Hargowilis. The subjects of this study were second grade students at SD Negeri Hargowilis, Kokap, Kulon Progo semester 1 of the 2018/2019 academic year. This research was conducted in two cycles, with each cycle consisting of action planning, action implementation, observation, and reflection. The results showed that the implementation of learning ablution material using the demonstration method could improve student learning outcomes in class II SD Negeri Hargowilis, Kokap, Kulon Progo. The increase in learning outcomes is indicated by an increase in learning activities by $15.2 \%$ and the number of students who achieve learning completeness as much as $90 \%$.
\end{abstract}

Keywords: Demonstration Method; Improvement; Learning Outcomes, Wudhu. 


\title{
$e^{\text {I-Tarbawj l'ing Hildah }}$
}

\begin{abstract}
Abstrak
Penelitian ini bertujuan untuk mengetahui peningkatan hasil belajar materi berwudhu setelah digunakan metode demonstrasi. Penelitian ini merupakan penelitian tindakan kelas yang dilaksanakan pada peserta didik kelas II di SD Negeri Hargowilis. Subyek penelitian ini adalah peserta didik kelas II d i SD Negeri Hargowilis, Kokap, Kulon Progo semester 1 Tahun Ajaran 2018/2019. Penelitian ini dilaksanakan dengan dua siklus, dengan masing-masing siklus terdiri dari perencanaan tindakan, pelaksanaan tindakan, observasi, dan refleksi. Hasil penelitian menunjukkan bahwa pelaksanaan pembelajaran materi berwudhu dengan menggunakan metode demonstrasi dapat meningkatkan hasil belajar peserta didik di kelas II SD Negeri Hargowilis, Kokap, Kulon Progo. Peningkatan hasil belajar tersebut ditunjukkan dengan adanya peningkatan aktivitas belajar sebesar $15.2 \%$ dan jumlah peserta didik yang mencapai ketuntasan belajar sebanyak $90 \%$.
\end{abstract}

Kata kunci: Metode Demonstrasi; Peningkatan; Hasil Belajar, Wudhu. 


\section{Pendahuluan}

Pendidikan merupakan sarana yang strategis dalam menanamkan sistem nilai yang berkembang dalam kehidupan. Sistem nilai tersebut meliputi ranah pengetahuan, kebudayaan, maupun nilai keagamaan. Proses pendidikan sudah seharusnya tidak hanya memberikan pengetahuan dan pemahaman, tetapi juga pembentukan sikap, perilaku, dan kepribadian peserta didik. Pada pelaksanaannya, proses pembelajaran perlu dikembangkan berdasarkan pengalaman belajar peserta didik dan menciptakan aktivitas pembelajaran yang menumbuhkan kerjasama, memberikan tantangan, namun tetap menyenangkan (Sabiq, 2006:47). Tugas pendidik dalam proses pembelajaran adalah membantu mempersiapkan dan mengembangkan peserta didik dalam aspek kognitif, afektif, maupun psikomotorik, serta mampu melaksanakan ketentuan agama dengan benar.

Tujuan yang akan dicapai dalam proses pembelajaran adalah mempersiapkan peserta didik agar menjadi manusia yang berbudaya tinggi. Namun pada pelaksanaannya, proses tersebut masih banyak yang dilaksanakan secara monoton. Hal tersebut dapat dilihat dalam pemilihan metode yang gunakan dalam pembelajaran, maupun pada media pembelajaran yang digunakan. Dampak yang dapat diamati secara langsung adalah masih rendahnya hasil pembelajaran yang dicapai oleh peserta didik. Untuk mewujudkan capaian pembelajaran yang maksimal, mengembangkan pembelajaran dengan inovasi- 


\section{$e^{\text {I-Tarbawj l'ing Hildah }}$}

inovasi perlu dilakukan oleh guru. Pengembangan pembelajaran, khususnya pada mata pelajaran Pendidikan Agama Islam dapat dilakukan dengan mengkombinasikan metode pembelajaran dalam proses penyampaian pembelajaran. Misalnya penggunaan metode ceramah dalam penyampaian pembelajaran materi praktek wudhu yang tidak dikombinasikan dengan metode lain kurang dapat memberikan gambaran yang jelas pada peserta didik. Kombinasi metode yang variatif misalnya dengan menggabungkan metode demonstrasi dengan media audio visual, diharapkan dapat membuat peserta didik mampu memahami sekaligus mempraktikkan materi tersebut secara langsung. Metode demonstrasi merupakan metode pembelajaran yang memberikan pengalaman langsung pada peserta didik untuk dapat mengamati, mendengarkan, bahkan merasakan seacara langsung proses yang disampaikan oleh guru (Roestiyah, 1995:83).

Kombinasi metode demonstrasi dan media audio visual juga dapat meningkatkan keaktifan peserta didik dalam mencoba dan pempraktikkan pembelajaran. Hal tersebut secara tidak langsung juga akan meningkatkan fokus peserta didik dalam belajar sehingga mampu meningkatkan hasil belajar. Menurut Tohirin (2008:151) hasil belajar merupakan pencapaian peserta didik terhadap apa yang telah ia pelajari dalam kegiatan belajar. Bentuk umum dari hal ini adalah penilaian dalam bentuk huruf ataupun angka oleh guru terkait 
kemampuan peserta didik dalam menguasai mata pelajaran. Hal terpenting dari hasil pembelajaran seperti yang dinyatakan oleh Oemar Hamalik (2004:30) adalah adanya perubahan tingkah laku pada orang tersebut, misanya dari tidak tahu menjadi tahu dan tidak mengerti menjadi mengerti.

Pada praktiknya, perbedaan hasil belajar dipengaruhi oleh kondisi peserta didik selama mengikuti kegiatan pembelajaran pembelajaran. Dalam pembelajaran mata pelajaran Pendidikan Agama Islam, penilaian hasil belajar dilakukan untuk pada dua aspek, yaitu aspek teori dan aspek praktik. Penilaian pada aspek teori sudah banyak dilakukan dan dikembangkan melalui penilaian kognitif yang dilakukan dalam bentuk tes sumatif maupun formatif. Namun penilaian pada aspek praktik belum banyak dikembangkan karena membutuhkan lebih banyak waktu dan tenaga yang diperlukan. Padahal menurut peneliti, kemampuan seseorang dalam melaksanakan praktik ibadah yang sesuai dengan ajaran agama merupakan tujuan akhir pembelajaran yang hendak dicapai, daripada hanya sekadar mengetahui teorinya saja. Hal inilah yang menjadi alasan peneliti untuk meneliti lebih dalam terkait penggunaan metode demonstrasi untuk meningkatkan hasil belajar mata pelajaran Pendidikan Agama Islam. Materi yang dipilih dalam penelitian ini adalah materi praktik wudhu. Materi ini dipilih karena kemampuan berwudhu sangat dibutuhkan sebagai dasar utama dalam pelaksanaan ibadah sehari-hari. Selain itu, wudhu juga merupakan perbuatan yang disyaratkan dengan 


\section{$e^{\text {I-Tarbawj l'ing Hildah }}$}

tegas seperti yang tertulis dalam QS. Al-Maidah ayat 6 yang berbunyi:

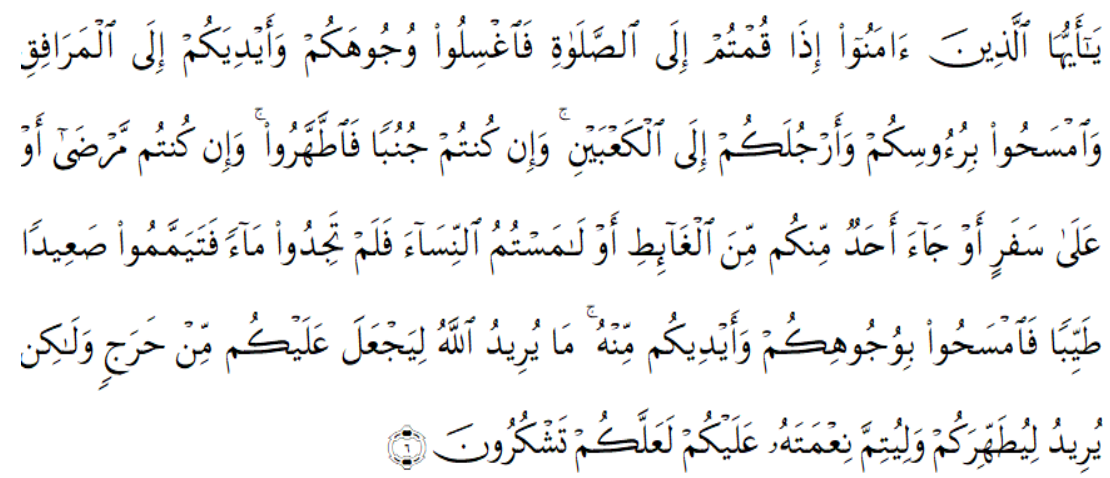

"Hai orang-orang yang beriman, apabila kamu hendak mengerjakan sholat, maka basuhlah mukamu dan tanganmu sampai dengan siiku, dan sapulah kepalamu dan (basuh) kakimu sampai dengan kedua mata kaki, dan jika kamu junub maka mandilah, dan jika kamu sakit atau dalam perjalanan atau kembali dari tempat buang air (kakus) atau menyentuh perempuan, lalu kamu tidak memperoleh air, maka bertayamumlah dengan tanah yang baik (bersih); sapulah mukamu dan tanganmu dengan tanah itu. Allah tidak hendak membersihkan kamu dan menyempuranakan nikmat-Nya bagimu, supaya kamu bersyukur". (QS.Al-Maidah: 6).

\section{Metode}

Penelitian yang dilakukan oleh peneliti termasuk dalam penelitian Tindakan kelas atau action research class. Tujuan utama dalam penelitian ini adalah untuk memecahkan masalah 
pembelajaran di kelas dan menaparkannya dalam bentuk deskripsi. Oleh karena itulah penelitian ini juga termasuk penelitian deskriptif, karena memberikan gambaran terkait sebuah proses pembelajaran dan hasil dari pembelajaran tersebut. Menurut Suharsimi Arikunto, kegiatan yang dilakukan dalam Penelitian Tindakan Kelas (PTK) adalah mencermati proses belajar yang dilaksanakan dengan mengacu pada rancangan yang telah dibuat dalam kelas yang telah ditentukan. Penelitian Tindakan Kelas dilakukan untuk menyelesaikan permasalahan yang dihadapi guru dalam pembelajaran sehingga mampu meningkatkan hasil belajar (Arikunto, 2010:3). Adapun rancangan dalam Penelitian Tindakan Kelas disusun sebagai berikut: 


\section{$e^{\text {I-Tarbawj l'ing Hildah }}$}

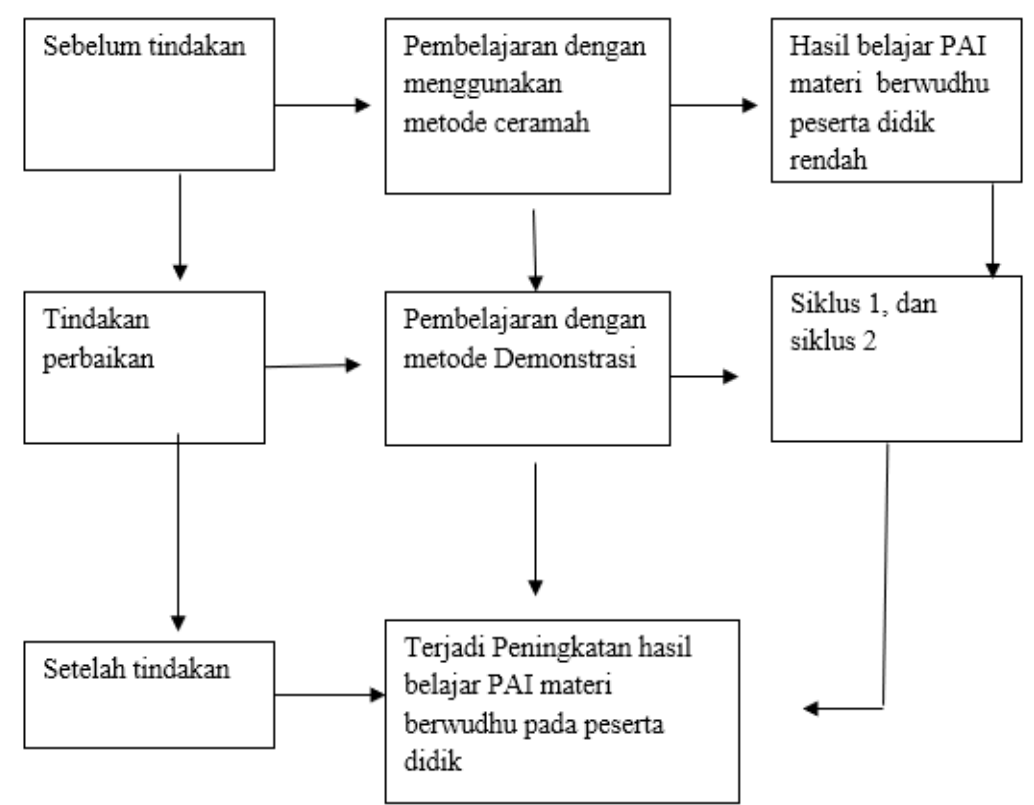

Gambar 1. Kerangka Berpikir

Penelitian ini dilaksanakan di SD Negeri Hargowilis Kokap Kulon Progo. Subjek penelitian adalah peserta didik kelas II yang berjumlah 10 peserta didik yang terdiri dari 7 peserta didik laki-laki dan 3 peserta didik perempuan. Penelitian ini menggunakan sumber data langsung yang diperoleh dari subjek penelitian yaitu peserta didik kelas II.

Pelaksanaan penelitian dilaksanakan dengan 2 siklus dengan masing-masing siklus terdiri dari perencanaan tindakan, pelaksanaan tindakan, observasi, dan refleksi. Perbedaan antara siklus 1 dan siklus 2 terdapat pada indikator materi yang diajarkan kepada peserta didik. Pada siklus II, materi yang disampaikan adalah pembahasan tentang doa 
setelah berwudhu. Analisis data dilakukan saat peserta didik melakukan proses pembelajaran dengan menggunakan lembar observasi kemudian data yang sudah diperoleh dipresentase dan dianalisis secara deskriptif. Untuk mengklasifikasikan frekuensi hasil belajar peserta didik dapat diuraikan seperti tabel dibawah ini:

\begin{tabular}{|c|c|}
\hline Interval Nilai & Klasifikasi \\
\hline $85-100$ & Sangat Baik \\
\hline $70-84$ & Baik \\
\hline $55-69$ & Cukup \\
\hline $40-54$ & Kurang \\
\hline $0-39$ & Sangat Kurang \\
\hline
\end{tabular}

Tabel. 1. Interval Nilai Hasil Belajar Peserta Didik

\section{Hasil Penelitian Dan Pembahasan}

Pelaksanaan penelitian pada siklus pertama maupun kedua dilakukan melalui beberapa tahapan, yaitu perencanaan tindakan, pelaksanaan tindakan, observasi, dan refleksi. Pada masing-masing tahapan terdapat beberapa kegiatan yang dilakukan oleh peneliti.

1. Tahap perencanaan tindakan.

Beberapa kegiatan dilakukan pada tahap perencanaan ini, dengan kegiatan yang pertama adalah membahas persiapan tindakan dengan melaksanakan pertemuan bersama guru. Kegiatan selanjutnya adalah menyusun rancangan 


\section{$e^{\text {I-Tarbawj l'ing Hildah }}$}

pembelajaran, termasuk diantaranya adalah menyusun dokumen-dokumen yang diperlukan seperti lembar kerja, lembar observasi, dan catatan lapangan aktivitas belajar peserta didik. Langkah berikutnya adalah penyusunan skenario pembelajaran dan dilanjutkan dengan mempersiapkan instrumen tes yang akan digunakan dalam tindakan pembelajaran.

2. Tahap pelaksanaan tindakan.

Pada proses pelaksanaan tindakan, peneliti melakukan hal-hal berikut: a. Memberi salam untuk membuka pembelajaran dan menyampaikan pada peserta didik kompetensi dasar yang ingin dicapai, b. Menginformasikan rancangan aktivitas pembelajaran yang akan diikuti oleh peserta didik di kelas, c. Memberikan materi pengantar tentang tata cara berwudhu dan memotivasi peserta didik pada awal pembelajaran, d. Menyiapkan peserta didik dan tempat demonstrasi, e. Membagi kelompok dalam belajar, $f$. Menunjukkan tempat praktek dan demonstrasi, g. Menjelaskan kepada peserta dididk bahwa kegiatan yang akan dilakukan adalah mendemonstrasikan tata cara berwudhu, $h$. Mengarahkan peserta didik untuk mencari tempat duduk bersama kelompok yang telah terbentuk, i. Menjelaskan pelaksanaan praktek dan demonstrasi yang akan dilaksanakan, j. Memberikan informasi mengenai tahapan yang harus dilalui dalam pelaksanaan pembelajaran demonstrasi, k. Mengevaluasi pelaksanaan diskusi yang diikuti oleh peserta didik, dan 1 . 
Memberikan tes di akhir pembelajaan untuk mengetahui hasil pembelajaran yang telah dilaksanakan.

Untuk mendapatkan data tentang hasil belajar peserta didik pada pembelajaran Pendidikan Agama Islam khususnya pada materi tata cara berwudhu maka digunakan instrument tes yang dilaksanakan setiap akhir pembelajaran pada tiap siklus I maupun II. Tes ini dilaksanakan pada pertemuan yang akan datang pada tiap siklus. Sebaran hasil pengamatan dan nilai hasil belajar peserta didik dapat dilihat melalui grafik dibawah ini:

\section{Grafik Frekuensi Hasil Belajar Peserta Didik Siklus}

I

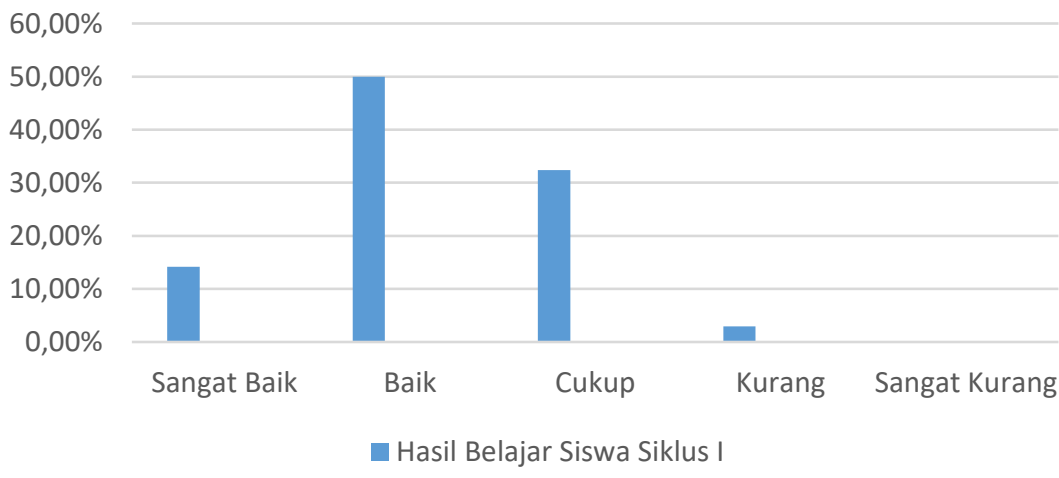

Grafik 1. Grafik Frekuensi Hasil Belajar Peserta Didik Siklus I

3. Tahap observasi

Observasi dilakukan untuk menggali informasi yang mendalam terkait aktivitas belajar dan suasana pembelajaran yang diikuti oleh peserta didik. Observasi dalam penelitian ini dilakukan untuk mengetahui proses pelaksanaan penelitian 


\section{$e^{I-T a r b a w j ~ l ' i n g ~ H i l d a h ~}$}

tindakan kelas. Hal yang perlu dicermati adalah apakah pelaksanaan penelitian sudah sesuai dengan tujuan penelitian. Selain itu dalam kegiatan observasi juga memastikan hasil pembelajaran yang diperoleh apakah sudah sesuai dengan indikator keberhasilan. Hasil observasi peserta didik dalam kelompok pada siklus I dan siklus II dapat dilihat sebagai berikut:

\begin{tabular}{|c|c|c|c|c|}
\hline \multirow{2}{*}{ No } & \multirow{2}{*}{ Interval Nilai } & \multirow{2}{*}{ Klasifikasi } & \multicolumn{2}{|c|}{ Kelompok } \\
\cline { 4 - 5 } & & Siklus I & Siklus II \\
\hline & $85-100$ & Sangat Baik & - & 1 dan 2 \\
\hline & $70-84$ & Baik & - & 3 \\
\hline & $55-69$ & Cukup & 2 dan 3 & - \\
\hline & $40-54$ & Kurang & 1 & - \\
\hline & $0-39$ & $\begin{array}{c}\text { Sangat } \\
\text { Kurang }\end{array}$ & - & - \\
\hline
\end{tabular}

Tabel 2. Observasi Peserta Didik Dalam Kelompok Pada Siklus I dan Siklus II

Dari data diatas diperoleh informasi bahwa terjadi peningkatan aktivitas peserta didik. Pada siklus I aktivitas peserta didik berada pada rentang nilai 55-69 dengan katageori cukup dan kurang dari 55 dengan kategori kurang. Pada siklus II aktivitas peserta didik mengalami peningkatan, 2 kelompok berada pada rentang nilai 85-100 dengan kategori sangat baik dan hanya satu kelompok berada pada rentang nilai 70-84 dengan kategori baik. Data tersebut menunjukkan bahwa keterlibatan peserta didik dalam kegiatan kelompok sudah 
maksimal dan merupakan indikasi bahwa metode demonstrasi berguna untuk membantu peserta didik dalam proses penyampaian materi pembelajaran.

Selain observasi peserta didik dalam kelompok, peneliti dibantu oleh guru yang lain untuk menilai peserta didik secara individu, hal ini dilakukan agar diketahui sejauh mana metode demonstrasi membantu dalam meningkatkan hasil belajar peserta didik. Adapun hasil observasi peserta didik secara individu sebagai berikut:

\begin{tabular}{|c|c|c|c|c|}
\hline \multirow{2}{*}{ No } & \multirow{2}{*}{ Interval Nilai } & \multirow{2}{*}{ Klasifikasi } & \multicolumn{2}{|c|}{ Individu } \\
\cline { 4 - 5 } & & & Siklus I & Siklus II \\
\hline & $85-100$ & Sangat Baik & - & 7 \\
\hline & $70-84$ & Baik & 4 & 2 \\
\hline & $55-69$ & Cukup & 6 & 1 \\
\hline & $40-54$ & Kurang & - & - \\
\hline & $0-39$ & $\begin{array}{c}\text { Sangat } \\
\text { Kurang }\end{array}$ & - & - \\
\hline \multicolumn{2}{|c|}{ Jumlah } \\
\hline
\end{tabular}

Tabel 3. Observasi Peserta Didik Dalam Individu Pada Siklus I dan Siklus II 


\section{$e^{I-T a r b a w j ~ l ' i n g ~ H i l d a h ~}$}

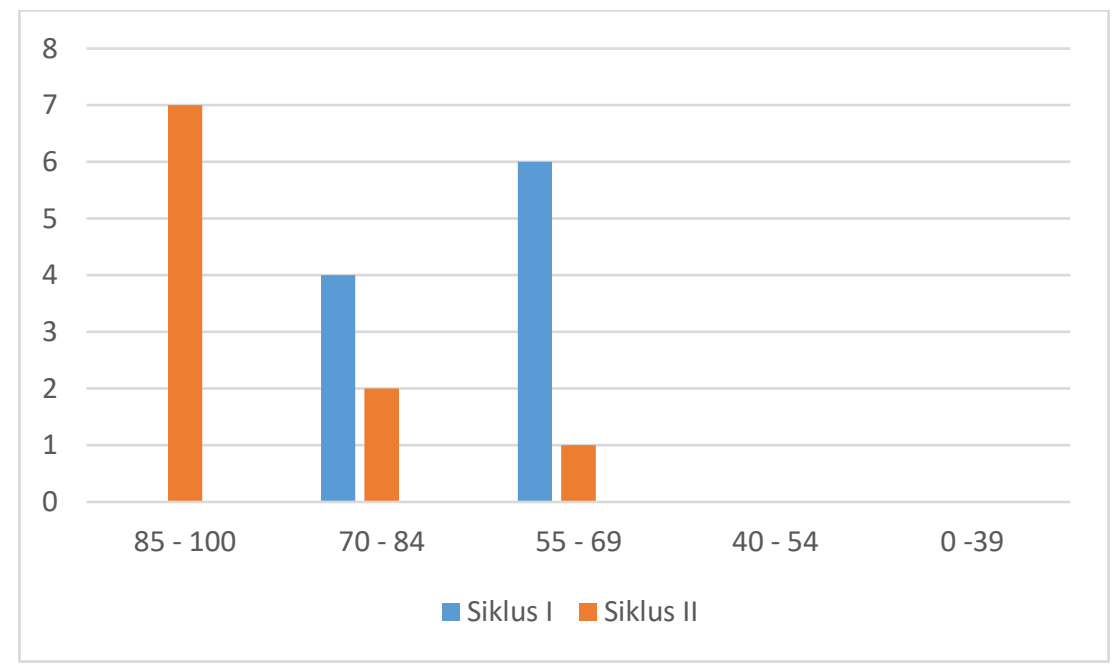

Grafik 2. Observasi Peserta Didik Secara Individu

Dari grafik diatas terdapat informasi bahwa terjadi kenaikan aktifitas peserta didik dari siklus I ke siklus II, peningkatan aktifitas peserta didik pada siklus I dengan kategori sangat baik maupun baik tidak ada data, namun pada siklus II hasil observasi menunjukkan bahwa adanya peningkatan yang dialami peserta didik dalam proses pembelajaran.

4. Tahap refleksi.

Setelah menyelesaikan satu siklus, peneliti bersama peserta didik melakukan diskusi untuk membahas hasil observasi yang berguna terhadap pelaksanaan hasil tindakan. Melalui kegiatan refleksi peneliti dapat melakukan evaluasi terhadap apa yang telah dilakukan. Hasil observasi kemudian dianalisis untuk dilakukan evaluasi dan diskusi, sehingga 
keduanya dapat dijadikan sebagai bahan refleksi untuk melakukan perbaikan tindakan pada proses pembelajaran pada siklus kedua. Tahap refleksi pada penelitian ini dilakukan setelah mencermati data-data hasil pelaksanaan dari masingmasing siklus. Data tersebut terdiri dari data pre test dan post test yang dilaksanakan pada siklus I dan siklus II.

Adapun hasil nilai pre Test, siklus I dan nilai post test pada siklus II sebagai berikut:

\begin{tabular}{|c|c|c|c|c|c|}
\hline \multirow{2}{*}{ No } & \multirow{2}{*}{ Rentang Nilai } & & & \multicolumn{2}{|c|}{ Jumlah Peserta Didik } \\
\cline { 4 - 5 } & & Pre-Test & Siklus I & Siklus II \\
\hline 1 & $51-60$ & & 4 & 1 & - \\
\hline 2 & $61-70$ & & 4 & 5 & 1 \\
\hline 3 & $71-80$ & & 2 & 3 & 1 \\
\hline 4 & $81-90$ & & 1 & 5 \\
\hline 5 & $91-100$ & & - & 3 \\
\hline \multicolumn{2}{|c|}{ Rata - Rata } & $\mathbf{6 4 , 0 0}$ & $\mathbf{7 0 , 1 0}$ & $\mathbf{8 5 , 3 0}$ \\
\hline
\end{tabular}

Tabel 4. Hasil Evaluasi Pembelajaran Saat Pre-Test dan Pada setiap Siklus I dan Siklus II

\section{Hasil Evaluasi Siswa}

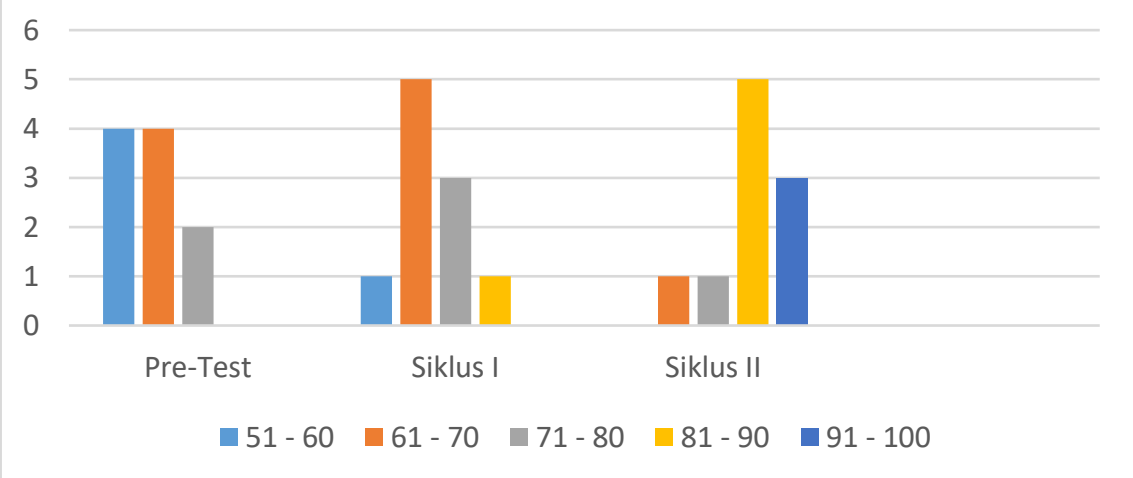




\section{$e^{I-T a r b a w j ~ l ' i n g ~ H i l d a h ~}$}

Grafik 3. Hasil Evaluasi Siswas Pada saat Pre Test serta Siklus I dan Siklus II

Dari grafik di atas didapatkan informasi bahwa sebelum diadakan Penelitian Tindakan Kelas, hasil tes yang diperoleh peserta didik saat pre test baru mencapai nilai rata-rata kelas sebesar 64,00 atau 20\% yang mencapai nilai KKM. Kemudian setelah diadakan tindakan pada siklus I perolehan nilai ratarata kelas naik menjadi 70,10 atau $40 \%$ peserta didik yang mencapai nilai KKM. Pada siklus II perolehan nilai rata-rata kelas naik mencapai 85,30 atau 90\% peserta didik yang mencapai nilai KKM. Dari hasil akhir pada siklus II yaitu sebesar $90 \%$ peserta didik yang mencapai nilai KKM menunjukkan sudah sesuai bahkan melampaui indikator keberhasilan penelitian yaitu $80 \%$ peserta didik mencapai nilai KKM.

Sedangkan peningkatan hasil belajar dalam bentuk prosentase dapat dilihat sebagai berikut:

\begin{tabular}{|c|c|c|c|c|c|}
\hline \multirow{2}{*}{ No } & \multirow{2}{*}{ Kategori } & & \multicolumn{2}{|c|}{ Jumlah Peserta Didik } \\
\cline { 3 - 5 } & & Pre-Test & Siklus I & Siklus II \\
\hline 1 & Siswa Tuntas & $2(20 \%)$ & $4(40 \%)$ & $9(90 \%)$ \\
\hline 2 & $\begin{array}{c}\text { Siswa Tidak } \\
\text { Tuntas }\end{array}$ & $8(80 \%)$ & $6(60 \%)$ & $1(10 \%)$ \\
\hline
\end{tabular}

Tabel 5. Prosentase Ketuntasan Minimal KKM 
Peningkatan Hasil Belajar Pai... el-Tarbawj

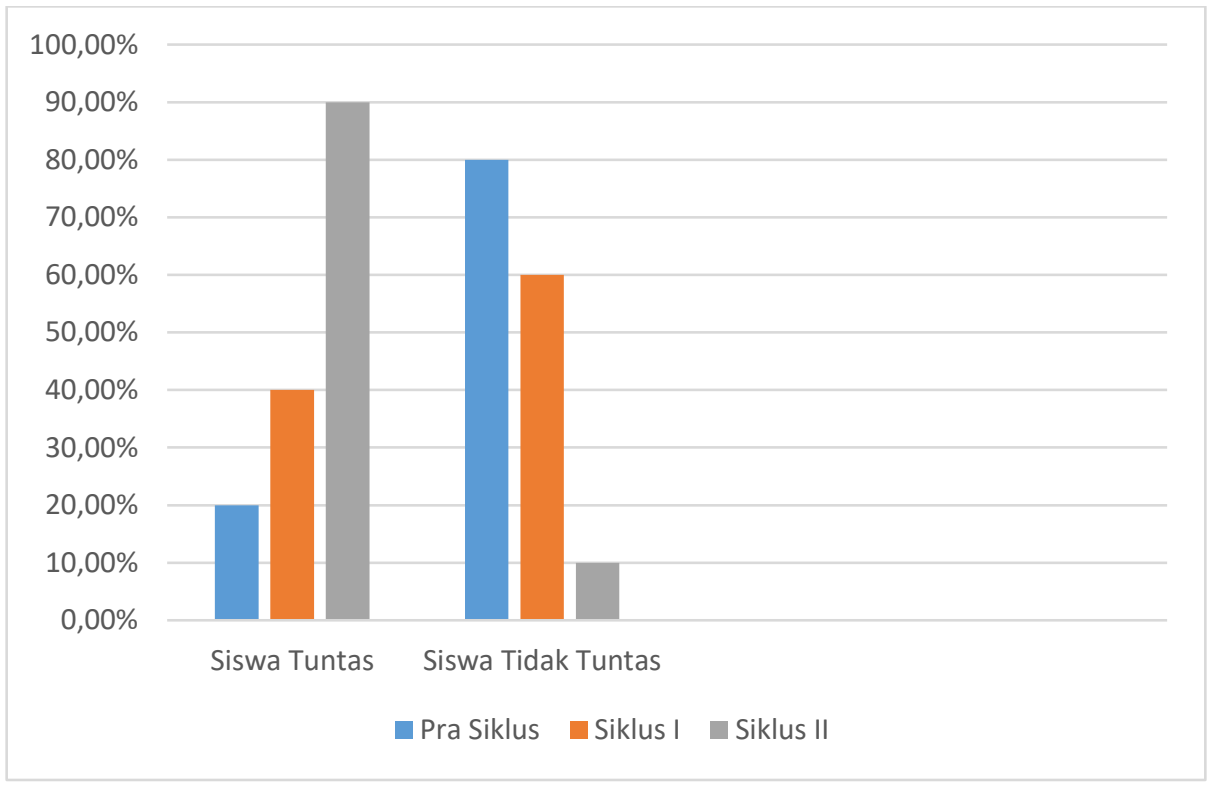

Grafik 4. Diagram Ketuntasan Minimal KKM

Data-data tersebut menunjukkan adanya peningkatan dalam aktivitas belajar peserta didik setelah diterapkannya strategi Demonstrasi dalam pembelajaran Pendidikan Agama Islam. Hasil dari siklus I menunjukkan persentase keberhasilan tindakan adalah sebesar 70,1\% dalam kategori sedang, sedangkan pada siklus II mengalami peningkatan menjadi $85,30 \%$. Selain itu, hasil belajar peserta didik melalui strategi demonstrasi pada materi berwudhu mata pelajaran Pendidikan Agama Islam juga mengalami peningkatan. Peningkatan hasil belajar peserta didik dapat dilihat dari jumlah peserta didik tuntas dan ketuntasan sesuai dengan KKM yang diharapkan. Jumlah peserta didik yang tuntas mengalami peningkatan dari 10 peserta didik pada siklus I yaitu 4 peserta didik dan 6 


\section{$e^{\text {I-Tarbawj l'ing Hildah }}$}

peserta didik dibawah nilai KKM, sedangkan pada siklus II dari 10 peserta didik yaitu 9 peserta didik mendapat nilai diatas KKM dengan kategori sangat baik dan baik serta 1 peserta didik yang dibawah nilai KKM dengan kategori kurang.

\section{Kesimpulan}

Penggunaan strategi demonstrasi pada materi berwudhu mata pelajaran Pendidikan Agama Islam dapat meningkatkan aktivitas belajar dan hasil belajar peserta didik kelas II di SD Negeri Hargowilis Kokap Kulon Progo. Peningkatan aktivitas belajar dari kedua siklus yang dilakukan adalah sebesar 15.2\% dan jumlah peserta didik yang mencapai ketuntasan belajar pada siklus terakhir adalah sebanyak $90 \%$. 


\section{Daftar Pustaka}

Agus Wasisto DD, 2018, Penelitian Tindakan Kelas \& cara menghitung nilai angka kreditnya, Yogyakarta, graha cendekia

Aminuddin Rasyad, 2002, Metode Pembelajaran Pendidikan Agama, Jakarta: Bumi Aksara.

Bagus Herdananto, 2009, Menjadi Guru Bermoral Profesional, Yogyakarta: Kreasi Wacana Offset.

Djamarah, Syaiful Bahri. 1997. Strategi Belajar Mengajar. Jakarta: Rineka Cipta.

Djamarah, Syaiful Bahri. 2000. Guru dan Anak Didik Dalam Interaksi Edukatif. Jakarta: Rineka Cipta.

Hamalik, Oemar. 2004. Proses Belajar Mengajar. Jakarta: PT Bumi Aksara

Hamalik, Oemar 2003. Media Pendidikan. Bandung : Citra Aditya Bakti.

Hasbullah. 1994. Dasar-Dasar Ilmu Pendidikan. Jakarta : Rajawali Press.

John M. Echols dan Hassa Shadily, 1984, Kamus Inggris Indonesia, Jakarta: PT. Gramedia.

Kartono, 1995, Psikologi Umum, Bandung : Mandar Maju.

Masykuri Abdurrahman dan Syaiful Bakri, 2006, Kupas Tuntas Salat: Tata Cara dan Hikmahnya, Jakarta: PT. Gelora Aksara Pratama. 


\section{$e^{\text {I-Tarbawj l'ing Hildah }}$}

Muhibbin Syah, 1995, Psikologi Pendidikan dengan Pendekatan Baru, Bandung: PT Remaja Rosdakarya.

Nana Sudjana. 2005. Penilaian Hasil Belajar Mengajar, Bandung : PT Remaja Rosdakarya

Roestiyah. 2001. Strategi Belajar Mengajar. Jakarta: PT Rineka Cipta.

Rifa'I, NH. 2002. Bimbingan Ibadah. Jombang: Lintas Media.

Sabiq. 2006. Fiqh Sunah. Jakarta: Pundi Aksara.

Sardiman. 1992. Interaksi dan Motivasi Belajar Mengajar. Jakarta : PT. Rajawali.

Slameto. 1998. Belajar dan Faktor-faktor yang Mempengaruhinya, Jakarta : PT. Rineka Cipta.

Syamsuddin Asyrofi, 2010, Metodologi Pembelajaran Bahasa Arab, Yogyakarta: Idea Press.

Syaifudin Azwar. 2002. Test Prestasi Fungsi dan Pengembangan Pengukuran Prestasi Belajar. Yogyakarta : Pustaka Belajar Offset

Sudjana. 2010. Sosiologi suatu pengantar, Jakarta : Grafindo Persada

Sugihartono. 2007. Psikologi Pendidikan. Yogyakarta: UNY Press.

Suharsimi Arikunto, dkk,2007, Penelitian Tindakan Kelas, Jakarta, Bumi Aksara. 
Syah Muhibbin. 1999. Metodologi Penelitian Agama .Jakarta : Grafindo Persada.

Tohirin. 2008. Psikologi Pembelajaran Pendidikan Agama Islam. Jakarta: PT Rineka Cipta.

Wina Sanjaya. 2009. Strategi Pembelajaran Berorientasi Standart Proses Pendidikan. Jakarta : Kencana Renada Media Group

Wahidmurni. 2010. Strategi Belajar Mengajar. Jakarta : Grasindo.

Winkel WS. 2007. Psikologi Pengajaran. Jakarta : PT. Grasindo

Yusuf Tayar,dkk,1997 Metodologi Pengajaran Agama dan Bahasa Arab, (Jakarta : PT. Raja Grafindo Persada)

Zakiah Drajat, 1995, Metodik Khusus Pengajaran Agama Islam, Jakarta: Bumi Aksara 